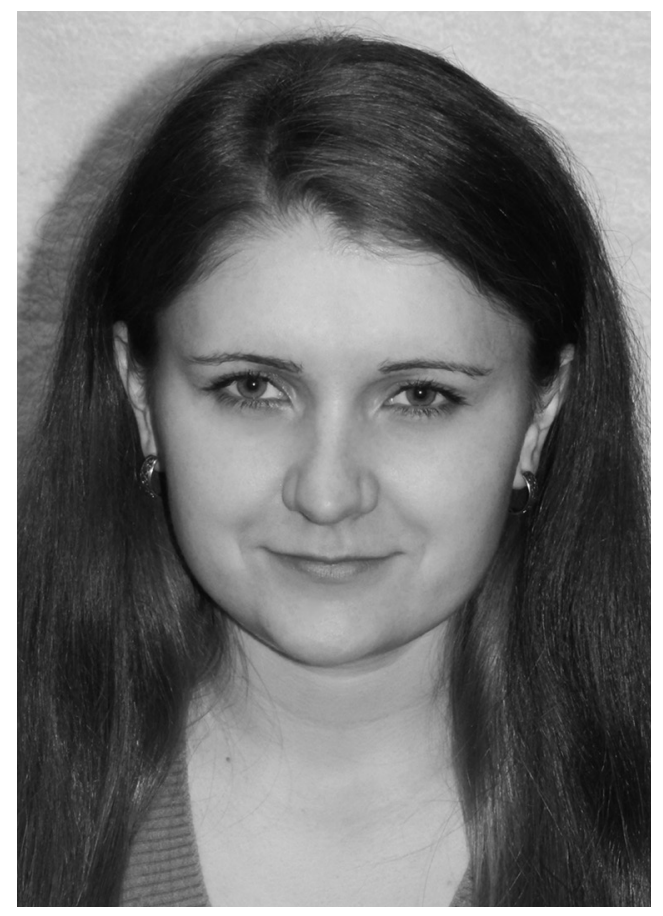

\section{УДК: 316.4}

DOI: https://doi.org/10.32689/2617-

2224-2020-1(21)-266-277

\section{Пономаренко Людмила Вікторівна,} провідний фахівещь відділу забезпечення міжнародних зв'язків управління комунікативними зв'язками Національної академї державного управління при Президентові України; 04050, м. Київ, вул. Пугачова, 12/2, тел.: (044) 4812195 , e-mail:plv_maren@ukr.net

ORCID: 0000-0001-9999-6335

\begin{abstract}
Пономаренко Людмила Викторовна, ведущий специалист отдела обеспечения международных связей управления коммуникативными связями Национальной академии государственного управления при Президенте Украинь; 04050, г. Киев, ул. Пугачева, 12/2, тел.: (044) 48121 95, e-mail:plvmaren@ukr.net
\end{abstract}

ORCID: 0000-0001-9999-6335

Ponomarenko Liudmyla Viktorivna,

Leading specialist of the International Relations Division, Communications Department, the National Academy for Public Administration under the President of Ukraine; 04050, Kyiz, Str.Puhachova, 12/2, tel.: (044) 481 2195, e-mail:plv_maren@ukr.net

ORCID: 0000-0001-9999-6335

\title{
МЕНТАЛЬНІСТЬ УКРАЇНСЬКОГО СУСПІЛЬСТВА ТА ÏÏ ВПЛИВ НА СУЧАСНІ ПРОЦЕСИ ІНСТИТУЦІОНАЛІЗАЦІЇ (АРХЕТИПНИЙ ПІДХІД)
}

Анотація. Розглянуто поняття ментальності українського суспільства, їі особливості та роль у формуванні типових життєвих реакцій суспільства, що відображають етнопсихологічні та соціокультурні особливості українського соціуму. Проаналізовано вплив ментальності на розробку та ефективність впровадження внутрішньої та зовнішньої політики, керування внутрішніми соціальними процесами, культурним розвитком тощо. На прикладах показано роль історичного досвіду у формуванні ментальності українського суспільства.

Виокремлено окремі архетипи - трудівника, кочівника, вчителя, жертви та воїна як такі, що мали суттєвий вплив на формування української 
ментальності, а через неї мають безпосередній вплив на процеси інституціоналізації в Україні, процеси державотворення та націєтворення. Зазначено, що через досвід попередніх поколінь українців значною мірою сформовано поведінкові та захисні реакції поколінь нинішніх, а також згенеровано певні страхи й комплекси у суспільстві.

Через архетип трудівника розглянуто стан та перспективи розвитку трудових ресурсів в Україні. У межах архетипу кочівника досліджено міграційні процеси в українському суспільстві. Роль інтелігенції в державотворчих та націєтворчих процесах проаналізовано через призму архетипу вчителя. У контексті архетипу жертви вивчено особливості світосприйняття українців як представників постколоніального суспільства. А через архетип воїна схарактеризовано найактивнішу, пасіонарну частину суспільства та її роль у розбудові держави та творенні нації.

Зазначено строкатість українського суспільства та фактори, які на це впливають. Визначено елементи, необхідні для формування здорового громадянського суспільства та гармонійного розвитку держави, творення нації. Підкреслено зв'язок між ментальністю суспільства та лідерськими якостями перших осіб, яких таке суспільство обирає.

Ключові слова: ментальність, суспільство, архетип, державотворення, націєтворення.

\section{МЕНТАЛЬНОСТЬ УКРАИНСКОГО ОБЩЕСТВА И ЕЕ ВЛИЯНИЕ НА СОВРЕМЕННЫЕ ПРОЦЕССЫ ИНСТИТУЦИОНАЛИЗАЦИИ (АРХЕТИПНЫЙ ПОДХОД)}

Аннотация. Рассмотрено понятие ментальности украинского общества, ее особенности и роль в формировании типичных жизненных реакций общества, которые отражают этнопсихологические и социокультурные особенности украинского социума. Проанализировано влияние ментальности на разработку и эффективность внедрения внутренней и внешней политики, управления внутренними социальными процессами, культурным развитием и т. д. На примерах показана роль исторического опыта в формировании ментальности украинского общества.

Выделены отдельные архетипы - труженика, кочевника, учителя, жертвы и воина как имевшие существенное влияние на формирование украинской ментальности, а через нее имеют непосредственное влияние на процессы институционализации в Украине, процессы формирования государства и нации. Отмечено, что через опыт предыдущих поколений украинцев в значительной степени сформированы поведенческие и защитные реакции поколений нынешних, а также сгенерированы определенные страхи и комплексы в обществе.

Через архетип труженика рассмотрены состояние и перспективы развития трудовых ресурсов в Украине. В рамках архетипа кочевника исследованы миграционные процессы в украинском обществе. Роль интеллигенции в процессах формирования государства и нации проанализирована сквозь 
призму архетипа учителя. В контексте архетипа жертвы изучены особенности мировосприятия украинцев как представителей постколониального общества. А через архетип воина охарактеризована самая активная, пассионарная часть общества и ее роль в развитии государства и создании нации.

Отмечена пестрота украинского общества и факторы, которые на это влияют. Определены элементы, необходимые для формирования здорового гражданского общества и гармоничного развития государства, создания нации. Подчеркнута взаимосвязь между ментальностью общества и лидерскими качествами первых лиц, которых такое общество избирает.

Ключевые слова: ментальность, общество, архетип, формирование государства, формирование нации.

\title{
MENTALITY OF UKRAINIAN SOCIETY AND ITS IMPACT ON MODERN PROCESSES OF INSTITUTIONALIZATION (ARCHETYPAL APPROACH)
}

\begin{abstract}
The article deals with the concept of mentality of Ukrainian society, its peculiarities and role in formation of typical life reactions of society, which reflect the ethno-psychological and socio-cultural features of Ukrainian society. The influence of mentality on development and effectiveness of national and foreign policy implementation, management of internal social processes, cultural development, etc. is analysed. The examples show the role of historical experience in mentality formation of Ukrainian society.
\end{abstract}

Separate archetypes are distinguished - toiler, nomad, teacher, victim and warrior, as those having significant influence on the formation of the Ukrainian mentality, and through it have a direct impact on the processes of institutionalization in Ukraine, the processes of state-building and nation-building. It is noted that due to the experience of the previous generations of Ukrainians, the behavioural and defensive reactions of the generations of the current ones have been largely formed, as well as certain fears and complexes in the society have been generated.

Through the archetype of the toiler the state and prospects for development of labour resources in Ukraine are studied. The nomad archetype explores migration processes in Ukrainian society. The role of the intelligentsia in state-building and nation-building processes is analysed through the prism of the teacher archetype. In the context of the victim archetype, the peculiarities of the worldview of Ukrainians as representatives of post-colonial society have been studied. And through the archetype of the warrior the most active, passionate part of society and its role in state-building and nation-building are characterized.

The diversity of Ukrainian society and the factors that influence it are noted. The elements necessary for the formation of a healthy civil society and the harmonious development of the state and the creation of the nation are identified. The relations between the mentality of the society and the leadership qualities of the top public officials chosen by such society are emphasized.

Keywords: mentality, society, archetype, state-building, nation-building. 
Постановка проблеми. Поняття ментальності можна охарактеризувати як специфіку сприйняття та тлумачення світу, властиву тому чи іншому народу, нації, соціальним суб'єктам, що уособлюється певними соціокультурними феноменами. Ментальність формується через поведінкові стереотипи, специфіку форм та способів їх виразу, інтелектуальні та емоційні реакції, що грунтуються на історичному досвіді, а також через архетипи культури та соціопсихологічну налаштованість соціальних суб'єктів. Ментальність формує типові життєві реакції суспільства, що відображають етнопсихологічні та соціокультурні особливості певних соціумів. Саме ментальність є ланцюжком, що єднає матеріальне та духовне у житті суспільства [1, с. 369].

Ментальність суспільства формує свого роду сценарій, що поєднує історичні, культурні, традиційні, поведінкові та емоційні, свідомі та підсвідомі елементи, за яким відбувається розвиток такого суспільства. На основі ментальності окремого народу і грунтуються його втрати та перемоги, зовнішня та внутрішня політика, економічне зростання та культурний розвиток, державо- та націєтворення.

Розуміння ментальності українського суспільства відіграє важливу роль для розробки та впровадження ефективної політики, керування внутрішніми соціальними процесами, культурним розвитком тощо.

Досвід попередніх поколінь українців має багате відображення в архетипах, що закладені в українських традиціях та культурі. Саме цей досвід і відіграє провідну роль у формуванні ментальності сучасного українського суспільства, що відрізняється доволі строкатим характером, і якому притаманні як позитивні, так і негативні риси.

Якщо проаналізувати ментальність українського суспільства, то можна спрогнозувати подальші перспективи розвитку Української держави, щоб уникнути помилок, які в минулому вже призводили до втрати свободи та незалежності.

Аналіз останніх досліджень i публікацій. Національна ментальність, національна ідентичність, національний характер неодноразово ставали предметом досліджень науковців, які підходили до вивчення українського суспільства 3 різних боків. Окремо вирізняються напрацювання у цій сфері у працях М. Грушевського, Д. Донцова, С. Кримського, В. Липинського.

Водночас питання формування національної свідомості та ментальності суспільства залишаються актуальними в процесах державо- та націєтворення в Україні.

Мета статті полягає в дослідженні ментальності українського суспільства та її впливу на сучасні процеси інституціоналізації у рамках архетипного підходу.

Виклад основного матеріалу. Українське суспільство відрізняється своєю традиційністю, консервативністю. Українці, у переважній своїй більшості, неохоче сприймають зміни та реформи, підсвідомо остерігаючись їх, що часто є виправдано, тримаючись давно усталених соціальних систем та норм. Як наслідок, українському суспільству властива 
певна інертність, очікування певного зовнішнього стимулу, “грому”, щоб “перехреститися”, тобто вжити конкретних активних дій.

Дуже вдало свого часу охарактеризував українське суспільство та його ментальність Микола Гоголь, відзначивши його своєрідну суперечливість, поєднання двох протилежних кольорів спектру, де з'єдналися “європейська обережність та азійська безтурботність, простодушність та хитрість, сильне діяльне начало та превеликі лінощі й млість, потяг до розвитку й вдосконалення - і між тим намагання здаватися таким, що зневажа досконалість” [2].

Українська ментальність успішно адаптується до викликів сьогодення, однак саме така її гнучкість і стає на перешкоді ефективності управлінських процесів у державі. Непослідовна внутрішня політика, а з нею політична, економічна, культурна i навіть територіальна невизначеність підвищують рівень тривожності та підозрілості у суспільстві.

Історичний досвід, на основі якого грунтується українська ментальність, в основному мав доволі травматичний характер - лише за останнє століття українці пережили дві світові війни, здобуття та втрату незалежності, голодомори, насильницьку колективізацію та русифікацію, масові репресіі, етнічні чистки тощо. Власна історія навчила українців остерігатися не лише чужих, а й своїх. Манкуртами, людьми без історичної пам'яті, і досі називають українців, які зрадили не тільки свій народ, а й самих себе [3].

На формування української ментальності великий вплив справили традиційні для українського суспільства архетипи, які об’єднали в собі досвід та шаблони поведінки попередніх поколінь. Серед архетипів, які особливо актуальні для розвитку Української держави сьогодні, варто виокремити, зокрема, архетипи трудівника, кочівника, вчителя, жертви та воїна. Саме вони формують строкатий образ сучасного українця, характер якого хоч і має певні відмінності залежно від регіону, але загалом поєднує ряд традиційних архетипів.

У ментальності будь-якої людини закладено певні сценарії, очікувані результати - від держави, суспільства і самих себе. Однак досвід попередніх поколінь українців не лише формує поведінку та захисну реакцію поколінь нинішніх, а й генерує певні страхи й комплекси у суспільстві. Відображенням же такої ситуації є цілий ряд ризикових для подальшого розвитку держави та i.. інституціоналізації тенденцій, які 3 роками набувають все більш загрозливого характеру.

Українці традиційно вважаються працелюбною нацією. В українській літературі міцно вкоренився архетипний образ роботящого українського селянина, хлібороба, справжнього господаря. I навіть наймитуючи, українець зазвичай зображується вмілим майстром своєї справи. Сучасний середньостатистичний українець вже не є землеробом. Однак його й досі вирізняють фаховість та працьовитість.

На жаль, наша держава нині переживає доволі складний період у сфері трудових ресурсів. Україна лишається однією з найбідніших євро- 
пейських країн, рівень оплати праці якої - один з найнижчих у Свропі. У той же час висококваліфіковані працівники з Україні високо ціняться в країнах Свропейського Союзу, куди вони зараз активно їдуть працювати, як і численні некваліфіковані працівники. Брак європейських трудових ресурсів поповнюється українськими заробітчанами, водночас український ринок праці залишається у програші, як і українська економіка загалом.

Негативний вплив на якість українських трудових ресурсів мав і радянський період української історії, коли українці працювали на державу, а не на власний достаток, тож єдиною “мотивацією” були лише каральні силові методи держави, як от розкуркулювання, насильницька колективізація, трудодні, відсутність паспортизації селян тощо.

Сучасний же ринок праці в Україні є логічним продовженням вже закладеної попередніми століттями реальності. У той час як частина громадян готова працювати та розвиватися, створювати власний бізнес та нові робочі місця, сплачувати податки у бюджет своєї держави, інша частина суспільства банально у цьому не зацікавлена та все ще сподівається на отримання певної гарантованої “залізної миски риса” від держави. I якщо в радянський період рівень прибутків практично не вирізняв представників різних професій між собою, то сьогодні ситуація кардинально змінилася. Розрив між прибутками багатих і бідних колосальний. Слабкість контролю 3 боку держави над походженням прибутків окремих громадян, вседозво- леність олігархату, робота “в тіні” та зарплати “в конвертах”, маніпуляції зі сплатою податків породжують напруженість та невдоволеність суспільства.

Велику роль відіграє у суспільстві і підсвідомий страх, що залишився у багатьох поколінь українців, які ще не забули, як у їхніх прадідів-підприємців, непманів, держава відбирала бізнес, а у прадідів-селян, хліборобів, - та ж держава вигрібала 3 комор весь провіант. Непередбачуваність державної політики ставить в уразливе становище сучасний малий та середній бізнес.

У ситуації, що має місце, держава виступає не гарантом стабільності, захисником інтересів найактивнішої частини свого населення, а швидше непередбачуваною каральною машиною, яка стримує не тільки розвиток власного підприємництва, а й перешкоджає іноземному інвестору заходити на український ринок.

Такі негативні тенденції свідчать про слабкість контролюючих та регулюючих функцій держави. Страх та невпевненість у завтрашньому дні гальмують розвиток українського бізнесу та й української економіки в цілому.

Питання трудових ресурсів тісно пов'язане ще $з$ однією загрозливою для України тенденцією - зовнішньою трудовою міграцією.

У силу політичних, соціальних, економічних чи ідеологічних чинників багато поколінь українців вирішували залишити власну домівку у пошуках кращої долі деінде, звертаючись до архетипу кочівника людини, вільної обирати свій шлях 
та рухатись уперед, залишаючи у минулому своє попереднє життя.

Декілька хвиль української еміграції, особлива друга - між світовими війнами та третя - після Другої світової війни, вкрай негативно відобразилися на українському суспільстві. Було втрачено частину найбільш активних та продуктивних верств населення: це й представники інтелігенції, церкви та проукраїнські політичні діячі, і військовослужбовці, які свого часу підтримали ідею української незалежності або як колишні військовополонені виявилися непотрібні радянському командуванню, і звичайні українці, які були приречені на винищення або еміграцію лише через власну національність.

Водночас за десятиліття еміграції вже для сучасної незалежної України було втрачено чимало блискучих вчених, висококваліфікованих фахівців та й просто працездатних людей. Трудова міграція приносить Україні мільярди доларів кожного року [4]. Однак ця цифра є свідченням катастрофічної економічної та соціальної ситуації в країні, адже свідчить про мільйони iㅣ громадян, які не змогли знайти роботу 3 достойною заробітною платою вдома і були змушені їхати на заробітки в інші країни [5]. Частина 3 них повернеться в України, але решту для країни буде втрачено. Такі перспективи б'ють не лише по економічному розвитку, а й по демографічному потенціалу України. Адже українська нація не тільки стрімко старішає, а ще й стабільно демонструє від’ємний природний приріст населення [6].
Якщо для попередніх поколінь мігрантів причини для виїзду за кордон мали швидше політико-ідеологічне підгрунтя, то для мігрантів нинішніх провідну роль відіграють фінансові чинники. А втрата молодого, працездатного населення є катастрофічною для держави, яка вже зіштовхнулася 3 кадровим голодом та 3 демографічною кризою. Держава не забезпечує базових суспільних потреб у соціальному захисті, працевлаштуванні, гідній оплаті праці тощо.

Однак поряд з базовими потребами - фізіологічними, безпековими та соціальними, у певному прошарку суспільства існує стійкий запит на задоволення більш високих потреб [7]. 3 точки зору управління масами значно перспективніше виглядає сценарій, за яким суспільство вдовольняється задоволенням лише базових потреб. Таким суспільством значно простіше керувати. Суспільство, зацікавлене у пізнанні нового, в духовному розвитку та самовдосконаленні, стає некерованою силою, здатною до аналізу та саморозвитку. Відсоток таких громадян завжди порівняно невеликий, однак їм характерна велика активність, пасіонарність, достатня, щоб “запалити” інших співгромадян, щоб змінити політичний курс цілої країни або захистити їі незалежність.

У кожній розвинутій спільноті є певні авторитети, які в силу власного досвіду чи знань, здатні істотно впливати не лише на громадську думку, а на суспільні процеси загалом. Традиційно така роль закріплюється за представниками інтелігенції - науковцями, дослідниками, ви- 
нахідниками, письменниками, митцями, лікарями тощо. Мова йде про той самий архетип вчителя, наставника, який 3 висоти свого досвіду здатний поділитися мудрістю, виконувати дорадницьку функцію. Але сьогодні свідомістю українського суспільства керують медійні персонажі, самозвані експерти-одноденки, блогери тощо.

У час інформаційних технологій українське суспільство звикло споживати інформаційний “фастфуд”. Інформація подається у вигідній, легкій для споживання формі, яка не вимагає аналізу чи осмислення. Сучасне українське суспільство вирізняється високою емоційністю, яку легко використовують у ворожій інформаційній війні. Відсутність ефективного контролю з боку держави за безсистемними, а часто й відверто ворожими інформаційними потоками, які спрямовуються на українське суспільство через засоби масової комунікації, призвела до ряду системних поразок України в інформаційному протистоянні з ворогом.

Причини такої ситуації можна відшукати, якщо знову ж таки звернутися до української історії, де й закрався збій у світосприйнятті суспільства. Представники інтелігенції здавна вважалися найбільш мислячою верствою населення. Пов'язано це в першу чергу з тим, що саме людина розумової праці, з грунтовною освітою та життєвим досвідом вчитель, лікар, священник, традиційно вважалася авторитетом в українському суспільстві. У радянський період ставлення до так званої інтелігенції було доволі зневажливим. У той же час представники української інтелігенції, особливо митці, які через власну творчість говорили 3 людьми зрозумілою тим мовою, вважалися ворожими, відверто шкідливими елементами, виразниками буржуазного націоналізму.

Мисляча інтелігенція відіграє важливу роль не лише для державотворення, а й для творення нації. Не дарма ж у радянський період знищення інтелігенції, як носія української ментальності, відбувалося особливо жорстко та цинічно. Одні лише розстріли української інтелігенції в урочищі Сандармох нанесли непоправні втрати українській культурі, наслідки яких відчуваються і по цей день. За один день напівосвічені виконавці-чекісти, можливо й не однією кулею на двох, як розповідається у популярному міфі про вбивство Миколи Куліша та Леся Курбаса, але позбавили українське суспільство великої частки його мислячої, активної еліти [8]. Їхніми руками радянська окупаційна влада змінила хід української історії назавжди.

Архетип вчителя певною мірою перегукується з архетипом лідера, гетьмана, авторитету, до якого дослухається вся нація. На жаль, постаті на кшталт Богдана Хмельницького чи Івана Мазепи трапляються в українській історії рідко. А більшість сучасних гетьманів не в силі втримати гетьманську булаву.

Українська ментальність ще в цілком собі монархічній Свропі відкинула принцип спадковості влади, зупинившись на виборчій системі, яка передбачала зміну старого гетьмана, як тільки він переставав бути виразником інтересів громади та її захисником. Ця сама ментальність сьо- 
годні не дозволяє покірно прийняти нав'язані ззовні шаблони поведінки. Як тільки народ розчаровується в моральному авторитеті чи в лідері, то без зайвих зволікань скидає того 3 п’єдесталу. Пошук українського гетьмана - нескінченний процес, як і наївна віра у доброго господаря, який швидко наведе лад у державі. Однак для наведення ладу необхідні драконівські мірі, що одразу ж викликає шалений опір тих, хто ще вчора голосував за вже згадане наведення ладу. Почути ж голос здорового глузду за хором маргіналів на манкуртів, які волають нині особливо гучно, практично неможливо.

Століття колоніального гніту, територіальна та культурна окупація наклали значний відбиток на ментальність українського суспільства, нагородивши його чималим переліком комплексів та психологічних бар'єрів. Страх перед фактичним знищенням та страх брати на себе відповідальність як за самого себе, так і за долю своєї країни, активували в ментальності українського суспільства архетип жертви. Людина не визнає себе жертвою, не усвідомлює себе такою, відмовляється бачити проблему загалом. Більше того жертва виправдовує свого кривдника. На українців можна приміряти й комплекс меншовартості, і навіть приписати своєрідний суспільний Стокгольмський синдром тощо. Іншим чином неможливо пояснити, чому після років фактичної російсько-української війни, загибелі тисяч військовослужбовців та мирних жителів, українці і досі бачать у сусідній державі друга та партнера. Кількість українців, які позитивно налаштовані до Росії, складає аж $57 \%$ У той же час до росіян, яких респонденти, очевидно, сприймають окремо від держави-агресора, в якій ті живуть і яку створюють, позитивно ставиться 77 \% українців [9].

Навіть після вторгнення російський військ в Україну, окупації українських земель, вбивств, катувань, інформаційної війни, брехні та зради українці не спроможні називати речі своїми іменами, а продовжують наївно вірити в дружбу народів та братні народи.

Жодні дії агресора не здатні відкрити очі "ментально контуженій" жертві. Складається враження, що кожному другому пересічному носію української ментальності конче необхідно радитися зі “старшим братом” щодо кожного свого хоч трохи важливого рішення, вдовольнятися другими ролями і мовчки спостерігати, як серйозні міжнародні партнери вирішать за нього його ж власні проблеми, не цікавлячись особливо, чи влаштовує таке рішення самого українця. Здобутий досвід перемог не додає такому українцю впевненості, а змушує ще більше сумніватися в собі, соромитися своїх успіхів та применшувати їх. Як писав у вступі до своєї поеми "Мазепа" Володимир Сосюра, "I гнів, і муку неозору співаю я в ці дні журби, коли лакеї йдуть угору й мовчать раби...” [10].

Але такій свого роду закомплексованості частини українського соціуму протистоїть їі друга частина, не вражена рабським менталітетом. Високі ставки у боротьбі за власну свободу та незалежність завжди надихали українців, активуючи у су- 
спільній свідомості архетип воїна. Зовнішня загроза завжди була найкращим каталізатором для виявлення у суспільстві жертв та воїнів, рабів та героїв.

Архетипний воїн цілком здатен протистояти ворогу не тільки на фізичному рівні, а й на ментальному - протистояти своїм страхам, зовнішньому навіюванню та штучним шаблонам поведінки. У сучасному українському суспільстві вже протягом тривалого часу простежується протистояння двох систем світобачення, двох ментальностей, в основі однієї з яких - архетип жертви, а другої - воїна. I якщо носії першої виразно сумують за минулим і прагнуть возз'єднатися зі своїм катом, якого щиро вважають рятівником, то носії ментальності воїна готові брати на себе відповідальність за долю власної країни, самостійно приймати рішення, а за потреби і захищатися - на донбаських териконах чи на теренах дипломатії, культури, науки, спорту. Поле бою для кожного воїна - це Україна.

Так вже історично склалося, що українці різних поколінь були змушені воювати зі своїми сусідами, протистояти їхнім імперським амбіціям. Це й породило свого роду ментальну установку, у наслідок якої у разі ворожої загрози "онуки хапали зі стіни дідову шаблю”. Подібні реакції властиві найактивнішим, пасіонарним представникам суспільства, які першими відповідають на виклики, які постають перед суспільством у часи випробувань. У той же час, вони є й найбільш уразливими, адже несуть пряму загрозу своїм противникам внутрішнім та зовнішнім.
Дійсно цікавим та обнадійливим для України є той факт, що нині в категорію захисника України потрапили не тільки безпосередньо військовослужбовці та добровольці. Тобто архетип воїна було активовано у ментальності усіх громадян, незалежно від їх статі, віку, освіти чи матеріального достатку, хто присвятив себе іншим видам боротьби - волонтерству, інформаційному супротиву, патріотичному вихованню тощо.

Висновки та перспективи подальших досліджень. У військовій боротьбі українське суспільство втратило велику частину своєї військової еліти. Репресивна радянська машина суттєво прорідила ряди української інтелігенції. Еміграція спричинила втрати серед активних та працездатних верств населення. Антиукраїнська внутрішня політика призвела до того, що українське суспільство почало втрачати свою національну ідентичність.

На світосприйняття сучасного українця впливає величезна кількість факторів, серед яких походження, виховання, освіта, регіон проживання, професія, рівень достатку та ін. Це є причиною диверсифікації у політичних поглядах, рівні готовності до змін, баченні бажаних цілей та шляхів для їх досягнення.

Успішна держава - це у першу чергу гармонійна держава, яку творять представники не тільки проукраїнської політичної еліти, але й свідомі громадяни, мисляча інтелігенція, креативні митці, боєздатна армія. У кожному суспільстві є і хлібороби, і воїни. Суспільство не може складатися лише з воїнів, хтось має вирощувати і хліб, щоб годува- 
ти своє військо. Процвітання своєї власної сильної держави та задоволення матеріальних і духовних потреб ㄲi громадян повинні бути тією метою, що дійсно з'єднає різні версти населення у єдине громадянське суспільство.

I важливу роль тут відіграє саме традиція, спадковість поколінь, хороша репутація, досвід та освіта. У процесах творення держави та нації, в управлінських процесах ці чинники повинні бути враховані в першу чергу. 3 хама, як кажуть у народі, не може бути пана. На жаль, щоб усвідомити цю просту істину, і виборець має бути не представником населення, яке прагне лише “хліба та видовищ”, а мислячим громадянином. Нація отримує тих керманичів, на яких заслуговує. Тож не дивно, що населення намагається обрати своїм лідером рівного собі, не розуміючи, що для розвитку держави та їі добробуту, лідер держави не може бути посередністю без знань та досвіду. Для будівництва будинку у першу чергу потрібен архітектор, а вже потім виконроб та будівельники. Це лише в радянські часи “кухарка” могли керувати державою. Не може керувати Українською державою i малорос, оскільки це вже пряма загроза національній безпеці, державним інтересам та самій незалежності як такій.

Справжній лідер держави, той самий архетипний гетьман, повинен мати три “П” - порядність, професіоналізм та патріотизм. І це правило має бути поширено не лише на першу особу, а на всіх державних службовців та посадових осіб місцевого самоврядування, на посадовців усіх рівнів.
Українське суспільство поступово позбавляється від штучних ментальних вкладок радянського виробництва, поволі повертаючись до власних коренів та традицій. Гіркі ліки дають найкращий результат для одужання українського суспільства. Сильну державу спроможні побудувати лише сильні громадяни, а вони в Україні є, і вони вже зробили свій рішучий крок на шляху до успішного творення Української держави та нації. Подальші наукові дослідження повинні відбуватися саме у цьому напрямі.

\section{СПИСОК ВИКОРИСТАНИХ ДЖЕРЕЛ}

1. Ментальність [Електронний ресурс]: Філософський енциклопедичний словник / за ред. В. І. Шинкарука. К.: Абрис, 2002. С. 369. Режим доступу: http://shron1. chtyvo.org.ua/ Shynkaruk_Volodymyr/Filosofskyi_ entsyklopedychnyi_slovnyk.pdf

2. Гоголь Н. В. Статьи из “Арабесок” [Електронный ресурс]. Режим доступа: http://gogol-lit.ru/gogol/ kritika-gogolya/vzglyad-na-sostavlenie-malorossii.htm

3. Манкурт [Електронний ресурс]. Режим доступу: http://sum.in.ua/f/ mankurt

4. За рік заробітчани переведуть в Україну 12,2 мільярда доларів прогноз НБУ [Електронний peсурс]. Режим доступу: https:// www. epravda.com.ua/news/2019/ 02/7/645072/

5. Сардалова Е. (Не)реальні цифри. Хто i як рахує українських заробітчан? [Електронний ресурс]. Режим доступу: https://www.radiosvoboda.org/a/news-skilky-ukraiintsiv-za-kordonom/29821865.html 
6. Демографічні тенденції в Україні потребують комплексного підходу на державному рівні [Електронний peсурс]. Режим доступу: https:// www.msp.gov.ua/news/14711.html

7. Піраміда потреб людини за Маслоу: 7 основних рівнів [Електронний pecypc]. Режим доступу: https://busines.in.ua/piramida-potreb-lyudynyza-maslou-7-osnovnyh-rivniv/

8. Винен... бо Куліш [Електронний ресурс]. Режим доступу: https:// www.radiosvoboda.org/a/24491111. html

9. Ставлення населення України до Росії та населення Росії до України, лютий 2019 року [Електронний pecypc]. Режим доступу: https:// kiis.com.ua/?lang $=\mathrm{ukr} \&$ cat $=$ reports \&id $=831 \&$ page $=1 \& \mathrm{t}=13$

10. Сосюра В. Мазепа [Електронний pecypc]. Режим доступу: https:// ukrclassic.com.ua/katalog/s/sosyuravolodimir/544-volodimir-sosyuramazepa-poema

\section{REFERENCES}

1. Mentalnist [Mentality]. (January 7, 2016). shron1.chtyvo.org.ua Retrieved from http://shron1.chtyvo. org.ua/Shynkaruk_Volodymyr/ Filosofskyi_entsyklopedychnyi_ slovnyk.pdf [in Ukrainian].

2. Hohol N. V. (2000) Stati iz "Arabesok" [Articles from "Arabesques"]. gogollit.ru Retrieved from http://gogol-lit. $\mathrm{ru} /$ gogol/kritika-gogolya/vzglyadna-sostavlenie-malorossii.htm [in Russian].

3. Mankurt [Mankurt]. (2013) sum. in.ua Retrieved from http://sum. in.ua/f/mankurt [in Ukrainian].

4. Za rik zarobitchany perevedut $\mathrm{v}$ Ukrainu 12,2 miliarda dolariv prohnoz NBU [Within a year, guest workers will transfer to Ukraine $\$ 12.2$ billion - the NBU forecast]. (February 7,2019 ) www.epravda.com.ua Retrieved from https://www.epravda. com.ua/news/2019/02/7/645072/ [in Ukrainian].

5. Sardalova E. (March 17, 2019) (Ne)realni tsyfry. Khto i yak rakhuie ukrainskykh zarobitchan? [(Not) real numbers. Who and how counts Ukrainian guest workers?]. www.radiosvoboda. org Retrieved from https://www.radiosvoboda.org/a/news-skilky-ukraiintsiv-za-kordonom/29821865.html [in Ukrainian].

6. Demohrafichni tendentsii v Ukraini potrebuiut kopleksnoho pidhkodu na derzhavnomu rivni [Demographic trends in Ukraine require a comprehensive approach at the state level]. (January 29, 2018) www.msp.gov.ua Retrieved from https://www.msp.gov. ua/news/14711.html [in Ukrainian].

7. Piramida potreb liudyny za Maslow: 7 osnovnykh rivniv [Maslow's hierarchy of human needs: 7 basic levels]. (November 13, 2017) busines.in.ua Retrieved from https://busines.in.ua/ piramida-potreb-lyudyny-za-maslou7-osnovnyh-rivniv/ [in Ukrainian].

8. Vynen... bo Kulish [Guilty...for being Kulish]. (February 21, 2012) www.radiosvoboda.org Retrieved from https://www.radiosvoboda. org/a/24491111.html [in Ukrainian].

9. Stavlennia naselennia Ukrainy do Rosii ta naselennia Rosii do Ukrainy, liutyi 2019 roku [Attitude of the population of Ukraine to Russia and the population of Russia to Ukraine, February 2019]. (March 12, 2019) kiis. com.ua Retrieved from https://kiis. com.ua/?lang $=\mathrm{ukr} \&$ cat $=$ reports\&id $=$ 831\&page $=1 \& \mathrm{t}=13$ [in Ukrainian].

10. Sosiura V. (2019) Mazepa [Mazepa]. ukrclassic.com.ua Retrieved from https://ukrclassic.com.ua/katalog/s/ sosyura-volodimir/544-volodimir-sosyura-mazepa-poema [in Ukrainian]. 